\title{
Comment on "The West Andean Thrust, the San Ramón Fault, and the seismic hazard for Santiago, Chile" by Rolando Armijo et al.
}

\author{
Ricardo A. Astini ${ }^{1}$ and Federico M. Dávila ${ }^{1}$ \\ Received 11 December 2009; revised 12 February 2010; accepted 28 May 2010; published 24 July 2010.
}

Citation: Astini, R. A., and F. M. Dávila (2010), Comment on "The West Andean Thrust, the San Ramón Fault, and the seismic hazard for Santiago, Chile" by Rolando Armijo et al., Tectonics, 29, TC4009, doi:10.1029/2009TC002647.

\section{Introduction}

[1] In a recent contribution, Armijo et al. [2010] provided a provocative model to interpret the kinematics and style of deformation of the central Andes at $\sim 33^{\circ} \mathrm{S}$ latitude (SL) in which they suggested that the Andes grew trenchward instead of cratonward. They challenge not only the hypothesis on building of the Andean belt but also the critical taper wedge model [Davis et al. 1983] and histories of thrust tectonics of different subduction systems like the South and North American Cordilleras. Armijo et al. [2010] assume that the "main" orogenic loading (represented by the cordilleran shortening) shifted westward generating a "foreland basin": the Chilean Central Depression, bounded to the west by the Coastal Cordillera.

[2] Our discussion is focused on the development of Andean basins and associated synorogenic sedimentary stratigraphy. We present three main lines of reasoning that, in turn, are interrelated: (1) thrust shifting, (2) basin formation along the Argentine foreland (considered explicitly by Armijo et al. [2010] as back-thrust-related basins), and (3) the Chilean Central Depression: a foreland basin?

\section{Thrusting}

[3] According to the critical taper wedge model [Davis et al. 1983; Stockmal et al., 2007], and disregarding isostatic compensation, the topographic and décollement dips (usually $\alpha$ and $\beta$, respectively) control the migration of deformation out of the zone of highest topography. When a certain critical angle $(\alpha+\beta)$ is exceeded (see Davis et al. [1983] and Hilley et al. [2004] for a specific example at this latitude in the Andes), the taper wedge rearranges, triggering forward deformation to reduce $\alpha+\beta$. This is translated into propagation of thrusts toward the regions of lower altitude (forward thrusting). In the Andes, the applicability of these mechanical principles has been clearly documented on the eastern flank, along the Principal Cordillera, the Frontal Cordillera, and the Argentine Precordillera fold and thrust

\footnotetext{
${ }^{1}$ Laboratorio de Análisis de Cuencas, Centro de Investigaciones en Ciencias de la Tierra, Universidad Nacional de Córdoba, Córdoba, Argentina.

Copyright 2010 by the American Geophysical Union. 0278-7407/10/2009TC002647
}

belts [see Allmendinger et al., 1990; von Gosen, 1992; Giambiagi and Ramos, 2002; Ramos et al., 1996, 2004; Cristallini and Ramos, 2000; Jordan et al., 2001; Hilley et al., 2004; Vergés et al., 2007, and references therein]. In these regions, the growth and synorogenic strata were progressively incorporated to the wedge top (i.e., the zone of thickened crust and high topography), while the thrust system migrated to the east. Jordan et al. [1993, 2001] have presented excellent reviews of the thrusting kinematics based on strata relationships. These details, however, cannot be explained kinematically nor mechanically using the Armijo et al. [2010] model, given that if the critical taper wedge migrates in the opposite sense, the thrust faults that adjust the position of mass in order to keep a stable wedge $(\alpha+\beta)$ also would migrate to the west. Although back thrusting (as well as out-of-sequence thrusting) might also assist to keep the wedge critical, the sequence of the individual faults should young toward the hinterland (to the west). This is not what is happening, as previously suggested. The propagation of shortening to the east, within the Precordillera, and the modern measurements of absolute crustal motion (also to the east), documented with GPS velocity fields [Brooks et al., 2003], are also in conflict with the Armijo et al. [2010] hypothesis.

\section{Basin Formation Along the Argentine Foreland}

[4] The kinematics of the thrust system and loading events on the eastern side of the Andean belt are strongly linked to basin formation. The wedge top migration and transport of orogenic topography to the east produced a progressive cratonward shifting of the tectonic load and, consequently, of the accompanying foreland depozones [cf. DeCelles and Giles, 1996] in that same direction. According to welldocumented isopach maps for several of the foredeep basins in Argentina [Yrigoyen, 1993; Jordan et al., 2001, Astini et al., 2005, and references therein], the areas of maximum thickness of synorogenic strata have progressively moved eastward since $\sim 20 \mathrm{Ma}$, developing accumulations $\gg 5 \mathrm{~km}$ thick in the modern transition zone between the Precordillera fold and thrust belt and the basement-involved Sierras Pampeanas [e.g., Fielding and Jordan, 1988; Zapata and Allmendinger, 1996]. In fact, at the latitude where Armijo et al. [2010] have decided to interpret their cross section across the Andes, the thicknesses of the synorogenic strata within the foreland has been sufficient to cause diachronous maturation of hydrocarbons in the productive Cuyo basin in Mendoza [Yrigoyen, 1993]; hence it is definitely not a 
"relatively shallow Cenozoic basin," as suggested by Armijo et al. [2010].

[5] This body of evidence cannot be explained using the opposite-vergent tectonic wedge of Armijo et al. [2010], given that the migration of tectonic loads would be in the opposite sense, with a resultant westward migration of the depozones and consequently of the foredeep strata (retrogradation or backward migration of the depozones). Moreover, this is strongly in conflict with the synorogenic stratigraphic arrangements, provenance, and paleoenvironmental development [see Johnson et al., 1986; Beer and Jordan, 1989; Reynolds et al., 1990; Yrigoyen, 1993; Damanti, 1993; Jordan et al. 1990, 1993, 2001; Milana et al., 2003] that show remarkable coarsening- and thickening-upward sequences, fully compatible with typical foreland basin dynamics (see Jordan [1995] for a thorough review).

\section{Chilean Central Depression: A Foreland Basin?}

[6] As previously noted by many workers [e.g., Jordan et al., 1993], both the synorogenic basin fill and the thrust wedge in the central Andes are impressively developed along the eastern side of the orogen, indicating a major asymmetry of the sedimentary flow in response to orogenic growth. This is in agreement with the dominant vergence of Andean structures and the well-established eastward propagation of deformation [James, 1971; Allmendinger et al., 1983, 1990; Jordan et al., 1983, 1993; Ramos 1988, 2009; Mpodozis and Ramos, 1989; Kley et al., 1999; Cristallini and Ramos, 2000; Giambiagi et al., 2001, 2003; Coutand et al., 2001; ANCORP Working Group, 2003; Ramos et al., 2004; Kay et al., 2005; Oncken et al., 2006].

[7] To the western side of the Cordillera, the Chilean Central Depression, immediately west of the inferred active main mountain front (WAT of Armijo et al. [2010]), is essentially a nonsubsiding, erosional, starved basin [Farias et al., 2008a, 2008b]. This "basin" accumulates only a few hundred meters of Quaternary alluvium, whereas Mio-Pliocene accumulations comparable to those in the Argentine counterpart are basically absent. This, together with the previous considerations, makes it very difficult to consider the Central Depression a "western foreland."

[8] Armijo et al.'s [2010] Figure 8a (addressed in their section 4.6) portrays that the uplift of the Coastal Cordillera could be interpreted as an "elastic fore-bulging ahead of the foreland flexure," driven by the WAT and "consequent loading by the weight of the Andes." Not only is there no sedimentologic or stratigraphic evidence provided to support such an interpretation, the flexural hypothesis is incompatible with preliminary flexural calculations. In the Armijo et al. [2010] "model," the wavelength of the "western foreland" is $\sim 20 \pm 10 \mathrm{~km}$ and the fore-bulge amplitude is of thousands of meters. No mechanically coherent approach can explain these magnitudes, even considering underestimations or overestimations of the tectonic loads and the elastic thickness. Also the "fore-bulge" wavelength far exceeds the wavelength of the supposed "foredeep," something in open contradiction with flexural mechanics [Turcotte and
Schubert, 1982; Watts, 2001]. Furthermore, it is very difficult to understand why the Central Valley "foreland" basin, which should have been several kilometers deep (between 4 and $6 \mathrm{~km}$ according to our calculations using the Cardozo and Jordan [2001] approach, for the loads reconstructed from Armijo et al.'s [2010] Figure 8a and elastic thicknesses between 20 and $40 \mathrm{~km}$ as suggested by Tassara et al. [2007]) should be sediment starved. The evolution of the Argentine foreland basins, facies patterns, sediment provenance, subsidence, the age of the sedimentary fill, and its relations with deformation and uplift has been thoroughly studied [e.g., Flemings and Jordan, 1990; Jordan, 1995]. However, none of these aspects were considered in any detail by Armijo et al. [2010] in reaching their interpretation that both the Coastal Cordillera and the Central Depression are a "western foreland," thus showing a poor understanding of foreland basin dynamics and the generation of accommodation space in a growing orogen. Nothing in their analysis of the Chilean Central Valley, lying between the subduction zone and the adjacent parallel magmatic arc, leads us to doubt the conventional view [cf., Dickinson, 1995] that the Central Depression is a part of the fore arc.

\section{Final Remarks}

[9] Orogenic models need to consider mass balance transfer during orogenic buildup, and this means that sediments and the sedimentary record cannot be ignored. This provocative new model for the Andes fails to account for the impressive foreland basin system developed along the eastern side of the Andean orogen. Contrary to this, the WAT, the active side of the orogen as interpreted by Armijo et al. [2010], shows minor associated sedimentation, and counterintuitively their "back-thrust system" provides instead the major sediment source. This is against general theory and modeling of sediment flow across orogens as a response of surface processes to tectonic and climate forcing [Beaumont et al., 1992, 2000; Kooi and Beaumont, 1996; Stolar et al., 2006; Whipple and Meade, 2006]. These works demonstrate the importance of surface processes and sediment flux in relation to tectonic and climate forcing, implying a linear behavior and response to surface uplift and strong asymmetry of sediment delivery. In the west vergent orogen of Armijo et al. [2010], the major topographic slopes located along the west side of the system should have enhanced precipitation and moisture discharge from the Pacific side of the orogen at $\sim 33^{\circ} \mathrm{SL}$, at least since the middle Miocene [e.g., Alpers and Brimhall, 1988; Jordan et al., 1997]. This should make an excellent combination to generate a large delivery of synorogenic sediments toward the inferred proforeland (the Central Depression in the Armijo et al. [2010] model) as well as a large magnitude of tectonic subsidence in which to preserve the sediment. Nevertheless, a Miocene-Quaternary sedimentary succession is poorly represented in the Chilean side, whereas on the Argentine slope, under a rain shadow effect, several thousand meters of Neogene sediments are recorded. So, how can the Chilean slope be interpreted as the leading edge of the tectonic wedge without maximizing the efficiency of sediment delivery, mass flux (with the natural orogenic asym- 
metry given by WAT plus climate forcing induced erosion), and sedimentary storage? Had Armijo et al. [2010] considered this question, their hypothesis might have been more robust.

[10] Any reasonable alternative to the currently accepted paradigm for development of the Andes (considered as the archetype of a mountain belt associated with subduction) has to keep in mind the unroofing history and the various feedback effects, including contrasting sedimentation and subsidence in retroside and proside of the orogen. Moreover, stratigraphic evidence should be kept in line with structural and geophysical observations. The sedimentary record in central Argentina and Chile contradicts a primarily westward vergence with a dominant influence of structures like the suggested WAT, thus raising substantial doubt that this case illustrates intracontinental subduction and "a mechanical substitute of a collision zone" as suggested by Armijo et al. [2010].

[11] The interpretation of Armijo et al. [2010] cannot explain the asymmetric distribution of synorogenic strata along the southern central Andes. Moreover, the excellent age constraints available for synorogenic deposits in the Argentine foreland do not support a southward younging of deformation as suggested by Armijo et al. [2010]. Absent that younging to the south, Armijo et al.'s [2010] proposal that the Andes at $33^{\circ} \mathrm{SL}$ are today under an "incipient stage of uplift" that might, eventually, evolve into a wider plateau-like morphology, similar to the Altiplano-Puna, seems like mere speculation.

[12] Last but not least, to propose that the Andes at $\sim 33^{\circ} \mathrm{SL}$ represent a belt "in an early stage of its evolution" seems also somewhat of an oversimplification, because as stated before, there is more than $20 \mathrm{Ma}$ record of synorogenic strata along the southern central Andes retroforeland [e.g., Ramos, 2009]. Clearly, this segment of the Andes is not in a stage of incipient orogenic growth. On this subject, the authors are in dire need of review of the complete and continuous synorogenic record preserved in western Argentina. Furthermore, their two-dimensional oversimplification ignores the important role of segmentation along the Andes that has been the matter of active research during the last 20 years or so [see Ramos, 2009, and references therein].

[13] Acknowledgments. An anonymous reviewer, the Editor, and Terry Jordan (for additional reading) are thanked for suggested improvements. We acknowledge Consejo Nacional de Investigaciones Científicas y tecnológicas (CONICET) and Fondo Nacional de Ciencia y Tecnología (FONCYT) for continued support to our research.

\section{References}

Allmendinger, R. W., V. Ramos, T. Jordan, M. A. Palma, and B. L. Isacks (1983), Paleogeography and Andean structural geometry, northwest Argentina, Tectonics, 2, 1-16, doi:10.1029/TC002i001p00001.

Allmendinger, R. W., D. Figueroa, D. Snyder, J. Beer, C. Mpodozis, and B. L. Isacks (1990), Foreland shortening and crustal balancing in the Andes at $30^{\circ} \mathrm{S}$ latitude, Tectonics, 9, 789-809, doi:10.1029/ TC009i004p00789.

Alpers, C. N., and G. H. Brimhall (1988), Middle Miocene climatic change in the Atacama Desert, northern Chile: Evidence from supergene mineralization at La Escondida, Geol. Soc. Am. Bull., 100, 1640-1656, doi:10.1130/0016-7606(1988)100< 1640:MMCCIT $>2.3 . \mathrm{CO} ; 2$.

ANCORP Working Group (2003), Seismic imaging of a convergent continental margin and plateau in the central Andes (Andean Continental Research Project 1996 (ANCORP' 96), J. Geophys. Res., 108(B7), 2328, doi:10.1029/2002JB001771.

Armijo, R., R. Rauld, R. Thiele, G. Vargas, J. Campos, R. Lacassin, and E. Kausel (2010), The West Andean Thrust, the San Ramón Fault, and the seismic hazard for Santiago, Chile, Tectonics, 29, TC2007, doi:10.1029/2008TC002427.

Astini, R. A., F. M. Dávila, O. López Gamundí, F. Gomez, G. Collo, M. Ezpeleta, F. Martina, and A. Ortiz (2005), Cuencas de la región precordillerana, in Frontera Exploratoria de la Argentina, edited by G. Chebli and L. Spalletti, pp. 115-145, Inst. Argent. del Pet. y del Gas, Buenos Aires.

Beaumont, C., P. Fullsack, and J. Hamilton (1992), Erosional control of active compressional orogens, in Thrust Tectonics, edited by K. R. McClay, pp. 1-18, Chapman and Hall, New York.

Beaumont, C., H. Kooi, and S. Willett (2000), Coupled tectonic-surface process models with applications to rifted margins and collisional orogens, in Geomorphology and Global Tectonics, edited by M. A. Summerfield, pp. 29-55, John Wiley, New York.

Beer, J. A., and T. E. Jordan (1989), The effect of Neogene tectonism of sandy, ephemeral deposition in the Bermejo basin, Argentina, J. Sediment. Petrol., $58,330-345$.
Brooks, B. A., M. Bevis, R. Smalley Jr., E. Kendrick, R. Manceda, E. Lauría, R. Maturana, and M. Araujo (2003), Crustal motion in the southern Andes $\left(26^{\circ}-36^{\circ} \mathrm{S}\right)$ : Do the Andes behave like a microplate? Geochem. Geophys. Geosyst., 4(10), 1085, doi:10.1029/2003GC000505.

Cardozo, N., and T. E. Jordan (2001), Causes of spatially variable tectonic subsidence in the Miocene Bermejo Foreland Basin, Argentina, Basin Res., 13, 335-357, doi:10.1046/j.0950-091x.2001.00154.x.

Coutand, I., P. R. Cobbold, M. de Urreiztieta, P. Gautier, A. Chauvin, D. Gapais, E. A. Rossello, and O. López-Gamundí (2001), Style and history of Andean deformation, Puna plateau, northwestern Argentina, Tectonics, 20, 210-234, doi:10.1029/ 2000 TC 900031.

Cristallini, E. O., and V. A. Ramos (2000), Thickskinned and thin-skinned thrusting in the La Ramada fold and thrust belt: Crustal evolution of the High Andes of San Juan, Argentina (32 $\left.{ }^{\circ} \mathrm{SL}\right)$, Tectonophysics, 317, 205-235, doi:10.1016/ S0040-1951(99)00276-0.

Damanti, J. F. (1993), Geomorphic and structural controls on facies patterns and sediment composition in a modern foreland basin, in Alluvial Sedimentation, edited by M. Marzo and C. Puigdefabregas, Spec. Publ. Int. Assoc. Sedimentol., 17, 221-233.

Davis, D., J. Suppe, and F. A. Dahlen (1983), Mechanics of fold-and-thrust belts and accretionary wedges, J. Geophys. Res., 88(B2), 1153-1172, doi:10.1029/JB088iB02p01153.

DeCelles, P. G., and K. A. Giles (1996), Foreland basin systems, Basin Res., 8, 105-123, doi:10.1046/ j.1365-2117.1996.01491.x.

Dickinson, W. R. (1995), Forearc basins, in Tectonics of sedimentary basins, edited by C. J. Busby and R. V. Ingersoll, pp. 221-261, Blackwell Sci., Cambridge, Mass.

Farías, M., R. Charrier, S. Carretier, J. Martinod, A. Fock, D. Campbell, J. Cáceres, and D. Comte (2008a), Late Miocene high and rapid surface uplift and its erosional response in the Andes of central Chile $\left(33^{\circ}-35^{\circ} \mathrm{S}\right)$, Tectonics, 27 , TC1005, doi:10.1029/2006TC002046.
Farías, M., S. Carretier, R. Charrier, J. Martinod, A. Tassara, A. Encinas, and D. Comte (2008b), No subsidence in the development of the Central Depression along the Chilean margin, paper presented at 7th International Symposium on Andean Geodynamics, Int. Symp. on Andean Geodyn., Nice.

Fielding, E. J., and T. E. Jordan (1988). Active deformation at the boundary between the Precordillera and the Sierras Pampeanas, Argentina and comparison with ancient Rocky Mountain deformation, in Interaction of the Rocky Mountain foreland and the Cordilleran Thrust Belt, edited by C. J. Schmidt and W. J. Perry, Mem. Geol. Soc. Am., 171, 143 163

Flemings, P. B., and T. E. Jordan (1990), Stratigraphic modeling of foreland basins: Interpreting thrust deformation and lithospheric rheology, Geology, 18, 430-435, doi:10.1130/0091-7613(1990)018< 0430:SMOFBI $>2.3$.CO;2.

Giambiagi, L. B., and V. A. Ramos (2002), Structura evolution of the Andes between $33^{\circ} 30^{\prime}$ and $33^{\circ} 45^{\prime} \mathrm{S}$, above the transition zone between the flat and normal subduction segment, Argentina and Chile, J. South Am. Earth Sci., 15, 101-116, doi:10.1016 S0895-9811(02)00008-1.

Giambiagi, L. B., M. Tunik, and M. Ghiglione (2001), Cenozoic tectonic evolution of the Alto Tunuyán foreland basin above the transition zone between the flat and normal subduction segment $\left(33^{\circ} 30^{\prime}\right.$ $34^{\circ} \mathrm{S}$ ), western Argentina, J. South Am. Earth Sci., 14, 707-724, doi:10.1016/S0895-9811(01)00059-1.

Giambiagi, L. B., V. A. Ramos, E. Godoy, P. P. Alvarez, and S. Orts (2003), Cenozoic deformation and tectonic style of the Andes, between $33^{\circ}$ and $34^{\circ}$ south latitude, Tectonics, 22(4), 1041, doi:10.1029/2001TC001354

Hilley, G. E., M. R. Strecker, and V. A. Ramos (2004), Growth and erosion of fold-and-thrust belts with an application to the Aconcagua fold-and-thrust belt, Argentina, J. Geophys. Res., 109, B01410, doi:10.1029/2002JB002282.

James, D. E. (1971), Plate tectonic model for the evolution of the central Andes, Geol. Soc. Am. Bull., 82, 
3325-3346, doi:10.1130/0016-7606(1971)82[3325: PTMFTE]2.0.CO;2.

Johnson, N. M., T. E. Jordan, P. A. Johnsson, and C. W. Naeser (1986), Magnetic polarity stratigraphy, age and tectonics setting of fluvial sediments in an eastern Andean foreland basin, San Juan province, Argentina, in Foreland Basins, edited by P. Allen and P. Homewood, Spec. Publ. Int. Assoc. Sedimentol., $8,63-75$.

Jordan, T. E. (1995), Retroarc foreland and related basins, in Tectonics of Sedimentary Basins, edited by C. J. Busby and R. V. Ingersoll, pp. 331-362, Blackwell Sci., Cambridge, Mass.

Jordan, T. E., B. Isacks, R. W. Allmendinger, I. A. Brewer, V. Ramos, and C. J. Ando (1983), Andean tectonics related to geometry of subducted Nazca Plate, Geol. Soc. Am. Bull., 94, 341-361, doi:10.1130/0016-7606(1983)94<341:ATRTGO> 2.0.CO;2.

Jordan, T. E., P. M. Rutty, L. E. McRae, J. A. Beer, K. Tabbutt, and J. F. Damanti (1990), Magnetic polarity stratigraphy of the Miocene Rio Azul section, Precordillera thrust belt, San Juan Province, Argentina, J. Geol., 98, 519-539, doi:10.1086/ 629422.

Jordan, T. E., R. W. Allmendinger, J. F. Damanti, and R. E. Drake (1993), Chronology of motion in a complete thrust belt: The Precordillera, $30^{\circ}-31^{\circ}$, Andes mountains, J. Geol., 101, 135-156, doi: $10.1086 / 648213$.

Jordan, T. E., J. H. Reynolds, and J. P. Erikson (1997), Variability in age of initial shortening and uplift in the central Andes, in Tectonic Uplift and Climate Change, edited by W. F. Ruddiman, pp. 41-61, Plenum, New York.

Jordan, T. E., F. Schlunegger, and N. Cardozo (2001), Unsteady and spatially variable evolution of the Neogene Andean Bermejo Foreland Basin, Argentina, J. South Am. Earth Sci., 14, 775-798, doi:10.1016/S0895-9811(01)00072-4.

Kay, S. M., E. Godoy, and A. Kurtz (2005), Episodic arc migration, crustal thickening, subduction erosion, and magmatism in the south-central Andes, Geol. Soc. Am. Bull., 117, 67-88, doi:10.1130/ B25431.1.

Kley, J., C. Monaldi, and J. Salfity (1999), Along-strike segmentation of the Andean foreland: Causes and consequences, Tectonophysics, 301, 75-94, doi:10.1016/S0040-1951(98)90223-2.

Kooi, H., and C. Beaumont (1996), Large-scale geomorphology: Classical concepts reconciled and integrated with contemporary ideas via a surface processes model, J. Geophys. Res., 101, 3361-3386, doi:10.1029/95JB01861.

Milana, J. P., F. Bercowski, and T. Jordan (2003), Paleoambientes y magneto estratigrafía del Neógeno de la sierra de Mogna, y su relación con la Cuenca de Antepaís Andina, Asoc. Geol. Argent. Rev., 58, 447-473.

Mpodozis, C., and V. A. Ramos (1989), The Andes of Chile and Argentina, in Geology of the Andes and Its Relation to Hydrocarbon and Mineral Resources, Earth Sci. Ser., vol. 11, edited by G. E. Ericksen, M. T. Cañas Pinochet, and J. A. Reinemund, pp. 5990, Circum-Pac. Counc. for Energy and Miner. Resour. Houston, Tex.

Oncken, O., J. Kley, K. Elger, P. Victor, and K. Schemmann (2006), Deformation of the central Andean upper plate system-Facts, fiction, and constraints for plateau models, in The Andes, Active Subduction Orogeny, edited by O. Oncken et al., pp. 3-27, doi:10.1007/978-3-540-48684-8 1, Springer, Berlin.

Ramos, V. A. (1988), The tectonics of the central Andes; $30^{\circ}$ to $33^{\circ}$ latitude, in Processes in Continental Lithospheric Deformation, edited by S. Clark, C. Burchfiel, and J. Suppe, Spec. Pap. Geol. Soc Am., 218, 31-54.

Ramos, V. A. (2009). Anatomy and global context of the Andes: Main geologic features and the Andean orogenic cycle, in Backbone of the Americas Shallow Subduction, Plateau Uplift, and Ridge and Terrane Collision, edited by S. M. Kay, V. A. Ramos, and W. R. Dickinson, Mem. Geol. Soc. Am., 204, 31-65, doi:10.1130/2009.1204(02).

Ramos, V. A., M. I. Cegarra, and E. Cristallini (1996), Cenozoic tectonics of the High Andes of westcentral Argentina $\left(30^{\circ}-36^{\circ} \mathrm{S}\right.$ latitude), Tectonophy sics, 259, 185-200, doi:10.1016/0040-1951(95) 00064-X

Ramos, V. A., T. Zapata, E. Cristallini, and A. Introcaso (2004), The Andean thrust system-Latitudinal variations in structural styles and orogenic shortening, in Thrust Tectonics and Hydrocarbon Systems, edited by K. R. McClay, AAPG Mem., 82, 30-50.

Reynolds, J. H., T. E. Jordan, N. M. Johnson, J. F. Damanti, and K. D. Tabutt (1990), Neogene deformation of the flat-subduction segment of the Argentine-Chilean Andes: Magnetostratigraphic constraintsfrom Las Juntas, La Rioja province, Argentina, Geol. Soc. Am. Bull., 102, 1607-1622, doi:10.1130/0016-7606(1990)102<1607:NDOTFS > 2.3.CO;2.

Stockmal, G. S., C. Beaumont, M. Nguyen, and B. Lee (2007), Mechanics of thin-skinned thrust-and-fold belts: Insights from numerical models, in Whence the Mountains? Inquiries Into the Evolution of Orogenic Systems: A Volume in Honor of Raymond A. Price, edited by J. W. Sears, T. A. Harms, and C. A. Evenchick, Spec. Pap. Geol. Soc. Am., 433 , 63-98, doi:10.1130/2007.2433(04)

Stolar, D. R., S. D. Willett, and G. H. Roe (2006), Climatic and tectonic forcing of a critical orogen, in: Tectonics, Climate, and Landscape Evolution, edited by S. D. Willett, N. Hovius, M. Brandon, and D. M. Fisher, Spec. Pap. Geol. Soc. Am., 398 , 241-250.

Tassara, A., C. Swain, R. Hackney, and J. Kirby (2007), Elastic thickness structure of the South America estimated using wavelets and satellite-derived gravity data, Earth Planet. Sci. Lett., 253, 17-36, doi:10.1016/j.epsl.2006.10.008

Turcotte, D. L., and G. Schubert (1982), Geodynamics: Application to Continuum Mechanics to Geological Problems, 450 pp., John Wiley, New York.

Vergés, J., V. A. Ramos, A. Meigs, E. Cristallini, F. H Bettini, and J. M. Cortés (2007), Crustal wedging triggering recent deformation in the Andean thrust front between $31^{\circ} \mathrm{S}$ and $33^{\circ} \mathrm{S}$ : Sierras PampeanasPrecordillera interaction, J. Geophys. Res., 112, B03S15, doi:10.1029/2006JB004287.

von Gosen, W. (1992), Structural evolution of the Argentine Precordillera: The Río San Juan section, J. Struct. Geol., 14(6), 643-667, doi:10.1016/ 0191-8141(92)90124-F.

Watts, A. B. (2001), Isostacy and Flexure of the Lithosphere, 458 pp., Cambridge Univ. Press, Cambridge, $\mathrm{U} . \mathrm{K}$.

Whipple, K. X., and B. J. Meade (2006), Orogen response to changes in climatic and tectonic forcing, Earth Planet. Sci. Lett., 243, 218-228, doi:10.1016/ j.eps1.2005.12.022.

Yrigoyen, M. R. (1993), Los depósitos sinorogénicos terciarios, in Geología y Recursos Naturales de la Provincia de Mendoza, edited by V. A. Ramos, pp. 123-148, Congr. Geol. Argent., Buenos Aires. Zapata, T. R., and R. W. Allmendinger (1996), Thrustfront zone of the Precordillera, Argentina: A thickskinned triangle zone, AAPG Bull., 80, 359-381.

R. A. Astini and F. M. Dávila, Laboratorio de Análisis de Cuencas, Centro de Investigaciones en Ciencias de la Tierra, Universidad Nacional de Córdoba, Av. Velez Sarsfield 1611, 2 Piso Of. 2, X5016GCA Córdoba, Argentina. (raastini@com. uncor.edu) 